\title{
SENSE PROCESSES IN TOURISM BOOKLETS
}

\author{
Shanty Dwi Krishnaningsih \\ Politeknik Manufaktur Negeri Bangka Belitung \\ shanty.azharudin@gmail.com
}

\begin{abstract}
This research tries to analyze the processes of sensing found in tourism booklets. Since the research only focuses on the processes of sensing, it is focused on the verbs. The data are collected from two booklets from Latvia's official tourism website. The method used is descriptive-qualitative. This analysis tries to answer three questions. They are the analyses of the sense processes, the types of sense processes, and the most and least sensing process verbs found from the analyses. From the analyses of the data, the emotive 'like' type verbs appear more than the other three sensing type verbs. The last finding is a desiderative verb, the verb wish.
\end{abstract}

Keywords: sense process, verbs, tourism

\begin{abstract}
ABSTRAK
Penelitian ini mencoba menganalisis proses penginderaan yang ditemukan dalam buklet wisata. Karena penelitian ini hanya berfokus pada proses penginderaan, maka difokuskan pada kata kerja. Data dikumpulkan dari dua buklet dari situs web pariwisata resmi Latvia. Metode yang digunakan adalah deskriptif-kualitatif. Analisis ini mencoba menjawab tiga pertanyaan. Mereka adalah analisis dari proses-proses indera, jenis-jenis proses indera, dan kata kerja proses pengindraan yang paling banyak dan paling sedikit ditemukan dari analisis. Dari analisis data, kata kerja tipe 'suka' muncul lebih dari tiga kata kerja tipe penginderaan lainnya. Temuan yang paling sedikit adalah kata kerja desiderative, kata wish.

Kata kunci: proses indera, kata kerja, pariwisata
\end{abstract}

\section{INTRODUCTION}

Talking about the process of sensing or in other words is called a mental process, it cannot be separated from Halliday's theory of Systemic Functional Linguistics (SFL). According to his third edition book (2004), An Introduction to Functional Grammar, the process of sensing as the focus of this research, is one of six type processes, which belongs to the clause as representation.

In line with (Halliday, Gerot and Wignell, 1995), the clause as representation or transitivity is related to interpersonal meaning, because there are three types of metafunction meanings, they are textual, interpersonal, and ideational ${ }^{2}$. It is stated before that interpersonal meaning relates to the clause as representation, which will be the exploration of this analysis, while the other metafunction meanings, textual will relate to the clause as a message and ideational relates to the clause as exchange. Clause as message explores theme and rheme in clauses, while clause as exchange explores mood and residue (Sujatna, 2012). (Gerot and Wignell, 1995) also explained 
that clause as representation refers to processes, participants, and circumstances. The processes here are related to the verbs' function, while the participants are the actors or the doers. The last term, circumstances, are the time, places, manner, cause, accompaniment, matter, and role Beside the mental process or process of sensing, the other five processes are material, relational, verbal, existential, and behavioral processes (Deterding and Poedjosoedarmo, 2001).

Structurally, each of the processes has a different name in the semantic roles, for example, material processes are processes of material doing and causing, so clauses with a material process obligatory have a doing (process/verb) and a doer (participant). Because the focus of the present research is the process of sensing, the participant roles are the senser and phenomenon.

The focus of this present research is taken from tourism booklets because of the first hypothesis, that there will be some verbs belong to the process of sensing found in them because generally, the tourism books will invite us to see the beautiful places by explaining why we must visit them. One of many ways to attract people's attention is by emphasizing the verbs of sensing in the tourism booklets. By emphasizing the mental process verbs, people will feel and think that they must go to the places suggested by the tourism booklets. The tourism booklets attract the readers to come and feel the beautiful places and taste the food through the words of the texts, which play the sensory capabilities. Furthermore, the data of the study were taken from the tourism booklets because mostly the data sources of the other researches are taken from the academic writings or the piece of arts, such as from the novels or the script of the movies. The reasons stated before are the background of this research.

The problem formulation of the present research is based on the theory of SFL, which tries, first, to analyze the process of sensing found in tourism booklets. Second, what kinds of process of sensing they are. Third, what the processes or verbs are found mostly in the tourism booklets. The present writer hopes that this research will extend the Linguistics knowledge and shows us the influence of the process of sensing verbs.

\section{LITERATURE REVIEW}

The writer uses the theories from the Systemic Functional Linguistic (SFL) or called as Functional Grammar (FG). There are some theories used, as the grand theories are from (Halliday and Matthiessen, 2004), and the supporting theories are from (Deterding and Poedjosoedarmo, 2001; Bloor and Bloor, 1995; Gerot and Wignell, 1994; Eggins, 2003; Sujatna, 2012).

As stated before in the introduction, the process of sensing is one of the six types of the processes in the clause as a representation that belongs to the SFL or FG. Functional grammar sees language as a tool to convey meaning. Another scholar, (Eggins, 2000), said the same as Halliday that "the kind of grammar most likely to 
have useful things to say to language learners and teachers." It means that functional grammar does not merely see grammar as the construction of language, or how language is structured, but also sees how language is used to deliver meaning.

(Halliday and Matthiessen, 2004) stated that there are three lines of meaning in the clause. First, the theme functions as a message. The clause has meaning as a message or a quantum of the information of what he is going to say. Second, the subject functions as an exchange or a transaction between the speaker and the listener. The last, the actor functions as a representation. The clause as the representation portrays as the one or the actor that does the deed.

There are six types of processes in the clause as the representation. They are material, mental, relational, verbal, existential, and behavioral processes (Deterding and Poedjosoedarmo, 2001). Mental processes or processes of sensing are one of the six processes that are also proposed by (Halliday and Matthiessen, 2004), that involve the clauses of feeling, thinking, wanting, and perceiving. Besides, (Bloor et al, 1995) states that mental processes involve not only material action but also the phenomena best described as states of mind or psychological events. Furthermore, he states that these processes "tend to be realized through the use of verbs like think, know, feel, smell, hear, see, want, like, miss, please, admire, enjoy, frighten."

(Halliday and Matthiesen, 2004; Deterding and Poedjosoedarmo, 2001; Sujatna, 2012), the mental process or the process of sensing is the process of thinking, feeling, and perceiving. As mentioned previously, the processes of the clause as the representative are realized by verbs. Regarding the process of sensing or the mental processes, (Halliday and Matthiessen, 2004) divide four classes of verbs, namely cognition, perception, desiderative, and emotive. The first, the cognition processes convey thinking. The verbs of cognition are the verbs of thinking, knowing, and understanding. The second, the perception processes convey perceiving through the five senses (Gerot and Wignell, 1995). The verbs of perception are the verbs of hearing, seeing, tasting, and smelling. The third, the desideration type, is the type of verbs such as want, desire, and wish. The last, as stated by (Halliday and Matthiessen, 2004), the verbs of emotive are like, love, and miss. Furthermore, (Matthiessen, 1995) states the emotive processes convey how someone feels about an object or an event. Based on the type of sensing, according, cognitive and desiderative belong to a higher level of sensing, while perceptive and emotive belong to a lower level. Based on the direction of sensing there will be emanating or 'like' type and impinging or 'please' type. Furthermore, phenomenon, the terminology is given by (Halliday, 2004) divides into two categories, 'specified' and 'unspecified'. There will be three sub-categories of specified phenomena. 


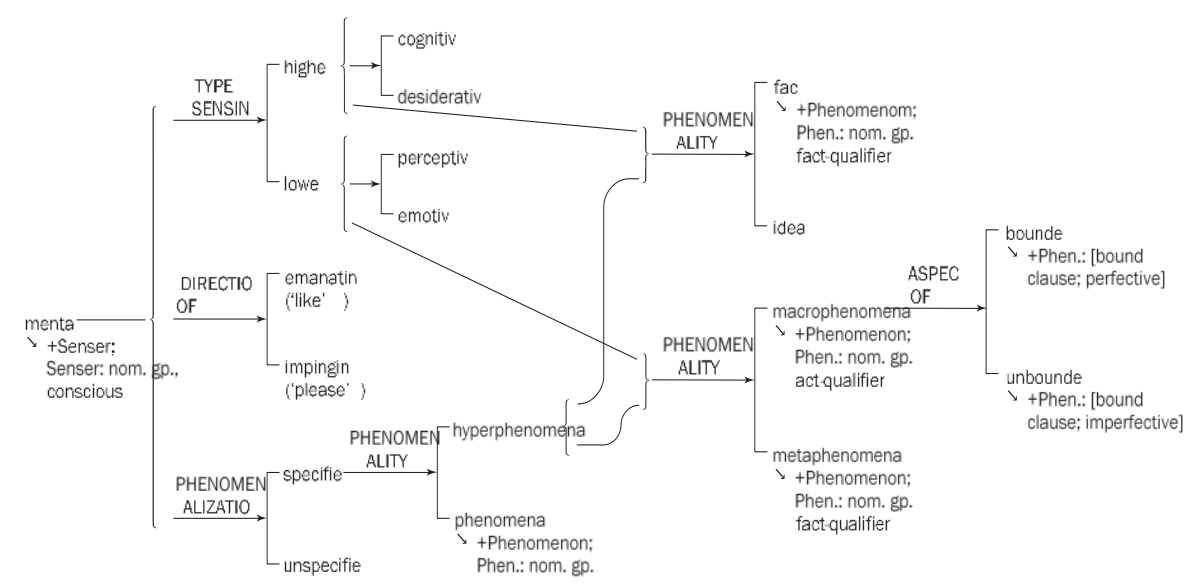

Figure 1. Mental Clause System by Halliday and Matthiesen\

Table 1. Examples of verbs serving as Process in mental clauses

\begin{tabular}{|c|c|c|}
\hline & 'like' type & 'please' type \\
\hline perceptive & $\begin{array}{l}\text { perceive, sense; see, notice, glimpse; } \\
\text { hear, overhear; feel; taste; the smell }\end{array}$ & (assail) \\
\hline \multirow[t]{2}{*}{ cognitive } & $\begin{array}{l}\text { think, belief, suppose, expect, consider, } \\
\text { know; }\end{array}$ & $\begin{array}{l}\text { strike, occur to, convince; } \\
\text { remind, escape; puzzle, }\end{array}$ \\
\hline & $\begin{array}{l}\text { understand, realize, appreciate; imagine, } \\
\text { dream, pretend; guess, reckon, } \\
\text { conjecture, hypothesize; wonder, doubt; } \\
\text { remember, recall, forget; fear } \\
\text { (think fearfully) }\end{array}$ & intrigue, surprise \\
\hline desiderative & $\begin{array}{l}\text { want, wish, would like, desire; hope } \\
\text { (for), long for, yearn for; intend, plan; } \\
\text { decide, resolve, determine; agree, } \\
\text { comply, refuse }\end{array}$ & (tempt) \\
\hline \multirow[t]{4}{*}{ emotive } & $\begin{array}{l}\text { like, fancy, love, adore, dislike, hate, } \\
\text { detest, despise, }\end{array}$ & $\begin{array}{l}\text { allure, attract, please, } \\
\text { displease, disgust, offend, }\end{array}$ \\
\hline & $\begin{array}{l}\text { loathe, abhor; rejoice, exult, grieve, } \\
\text { mourn, bemoan, }\end{array}$ & $\begin{array}{l}\text { repel, revolt; gladden, delight, } \\
\text { gratify, sadden, }\end{array}$ \\
\hline & $\begin{array}{l}\text { bewail, regret, deplore; fear, dread; } \\
\text { enjoy, relish, }\end{array}$ & $\begin{array}{l}\text { depress, pain; alarm, startle, } \\
\text { frighten, scare, }\end{array}$ \\
\hline & marvel & $\begin{array}{l}\text { horrify, shock, comfort, } \\
\text { reassure, encourage; amuse, } \\
\text { entertain, divert, interest, } \\
\text { fascinate, bore, weary, worry }\end{array}$ \\
\hline
\end{tabular}


Table 1. above is taken from (Halliday, 2004) and is used for analyzing the categories of the sensing or mental verbs found in Latvia's tourism booklets. If there is no verb mentioned in the data source, the writer uses the synonyms of the verbs to analyze the data.

There are some researches about the process of sensing, three of them are Sujatnas' Sundanese Verbs in Mental Processes: A Systemic Functional Linguistic Approach, Applying Systemic Functional Linguistics to Bahasa Indonesia Clauses, and Processes in Bahasa Indonesia Tourism Promotion Texts and Its Equivalence in English: A Systemic Functional Linguistic Study. While she explores the Sundanese verbs, Bahasa Indonesia clauses, and the analyses of two major types of clauses: verbal clauses and nonverbal clauses, but also four processes in the tourism promotion texts, this research only tries to analyze the processes of sensing found in the tourism booklets.

\section{RESEARCH METHOD}

The writer uses the descriptive-qualitative method. This combination method is used because the writer only tries to analyze the data by giving descriptive explanations by collecting then analyzing the data. According to (Lexy, 1993), the qualitative data are the data that contain non-statistic such as sentences, photography, sound recording, and picture. Based on the theory stated above, therefore, the design that is applied in this paper is the descriptive-qualitative method. The descriptive method analyzes the data from words, pictures, or it can be numeral of statistics (Bodgan and Taylor in Lexy, J. Maleong, 1993). The data source is taken from the tourism booklets on Latvia's official tourism website. After collecting the data from the booklets, since the focus of the study is on the process of sensing or the mental processes, the next step, the writer classifies the four classes of the verbs: the cognition, the perception, the desiderative, and the emotive verbs. After being classified, the next step is to identify what kinds of process of sensing they are. As the last step, the writer tries to describe the dominant or the most process verbs found in the tourism booklets.

\section{FINDING AND DISCUSSION}

\section{Finding}

The writer analyzes 34 data as the samples from three tourism booklets taken from Latvia's official tourism website in 2013. As stated previously, the writer tries to solve three problems. First, the writer analyzes the process of sensing found in tourism booklets. Second, what kinds of process of sensing they are. Third, what the processes or verbs are found mostly in the tourism booklets. In Latvia's tourism booklets, it can be found that the process of sensing, as follows:

Data 1: Jürmala attracts visitors with its pleasant climate, old wooden architecture, historical charm, and wealth of natural resources - ionized, sea- and 
phytoncide-enriched pine forest air, quartz sand beaches, mineral waters, and therapeutic mud.

Taking a look at the first datum above, the writer found a verb 'attract'. According to Fig. 5-15 of Mental Clause System from (Halliday and Mattiessen, 2004), the chart and also the table 5 (10) of Examples of verbs serving as the process in the mental clause, the verb 'attracts' above belongs to emotive sensing type and impinging or 'please' type.

Data 2: Ayurveda, one of the most ancient and frequently practiced lifestyle teaching systems, sees the human body as a unified whole, in which all processes should take place naturally and freely.

The same as the first analysis, from the second datum, the mental process verb is 'sees'. Based on the type of sensing, it belongs to a perceptive category, while based on the direction of sensing, it is an emanating or 'like' type.

Data 3: You can enjoy the benefits of juice therapy in Jürmala, at the Baltic Beach Hotel and the Jantarnij Bereg health resort.

The sensing process in the third datum is 'can enjoy', which belongs to emotive sensing type and a 'like' type verb.

Data 4: Beauty services are a top priority of health tourism in Latvia, and not without reason - since beauty treatments are not seasonal, they can be enjoyed throughout the year.

There are three clauses in the sentences above and two processes, two clauses in the first and second clause are relational processes, and the last clause is the mental process. The verb of sensing process found is 'can be enjoyed', which belongs to emotive sensing type and a 'like' type verb.

Data 5: Furthermore, coming to Latvia for health improvements and other procedures and services is far more discrete than staying at home - as no one knows you here, you can choose to be less public about it.

From the datum above, there are three clauses and the mental process found is the verb 'knows'. It is categorized as the cognitive 'like' type verb.

Data 6: Take the time to pamper your face and body and you'll feel the difference within!

The sixth datum shows two clauses and two processes, that are the material and mental process. The mental process verb of the sentence above is 'will feel'. It is classified as a perceptive 'like' type verb.

Data 7: The sauna attendant will know whether to stop at raising some steam, give you some gentle strokes with the birch besom, or to go all out with it.

There are four clauses and two processes. The first clause is the mental process, while the second to the last clause are material processes. The verb of 
sensing process is 'will know', which belongs to a cognitive 'like' type verb.

Data 8: Like every ritual activity, steaming also has its unwritten laws, and some of them should be known to every sauna goer.

The verb found above is 'should be known' and it belongs to a cognitive 'like' type verb.

Data 9: The clinic is known for its state-of-the-art equipment, highly qualified medical staff, and excellent surgery results.

The analysis of the ninth datum is the same as the analysis of the seventh and eighth data. The process of sensing a verb is 'is known' and it is categorized as a cognitive 'like' type verb.

Data 10: And when you wade into the sea, the soles of your feet will sense the raised patterns in the sand-a massage felt by the whole body.

The datum above shows three clauses. The first clause is a material process, while the second and the third clauses are mental processes. The verbs of the mental processes are 'will sense' and 'felt'. Both of them belong to perceptive 'like' type verbs.

Data 11: If you're not feeling very energetic, take a stroll along the white sand, giving the soles of your feet a natural massage.

There are three clauses in the datum above. The process of sensing is only found in the first clause. The process verb of the datum above is 'are not feeling'. It belongs to a perceptive 'like' type verb.

Data 12: On the quiet, secluded beaches you'll feel like the only person on earth, and the healthy, phytoncide-rich coastal forest air will ease your breathing.

From the twelfth datum, it can be found that there are two clauses. The first clause is the mental process, while the second one is a material process. The verb of the mental process is 'will feel'. It belongs to a perceptive 'like' type verb.

Data 13: For the best possible experience, however, take the time for a several-day boat trip - you'll enjoy swimming, savour freshly caught fish, and delight in the picturesque and unusual scenery of the river and its banks.

The datum above shows four clauses and two processes. The first clause is a material clause. The second, third and the last clause are mental processes. The verbs of the mental process above are 'will enjoy', 'savour', and 'delight'. The verbs 'will enjoy' and 'savour' have a similar meaning and the same categories as the emotive 'like' type verbs, while the verb 'delight' belongs to emotive 'please' type.

Data 14: In spring and autumn you can see salmon and vimba bream dancing above the water here (as well as in other rivers).

The datum above reflects the mental process by the predicate 'can see'. It is 
classified as a perceptive 'like' type verb.

Data 15: Climatic conditions of high relative humidity and a long growing season have encouraged Latvia's biodiversity, and its fields, forests, countryside, water, and soil hide a whole store of natural remedies.

There are two clauses in the datum above. They are mental and material processes. The mental processes above are 'have encouraged'. It belongs to emotive 'pleased' type verb.

Data 16: The best things in life should be savoured and enjoyed slowly.

The clause above is complex because there are two predicates. The two predicates belong to the same categories of emotive 'like' type verbs.

Data 17: Delight in Latvia's magnificent architecture, culture, and music.

The verb of sensing process from the datum above is 'delight', which belongs to emotive 'please' type verb.

Data 18: Taste delicious naturally produced Slow Food.

The word 'taste' above is categorized as perceptive 'like' type verb.

Data 19: Enjoy unique seasonal celebrations, festivals, and sporting events.

From the datum above, it shows that the verb 'enjoy' belongs to emotive 'like' type verb.

Data 20: With more than 30 castles and medieval fortresses, the vast majority dating back to the thirteenth and fourteenth centuries, you will feel the spirit of chivalry and the mystique of the middle-ages with every thoughtful step you take.

There are two clauses in the datum number 20. They are mental and material process. The mental process found is 'will feel.' It belongs to a perceptive 'like' type verb.

Data 21: Admire the texture, shades, colours, and contours of Latvia's premier art works.

The clause above contains the verb 'admire', which belongs to emotive 'like' type verb.

Data 22: Whether it is the powerful rock music of Pete Anderson, the anthemic pop tunes of Brainstorm, or the Memphis-inspired songs of the truly excellent Latvian Blues Band, your ears will delight in the musical journey that awaits them in Latvia.

There are three clauses found from the datum above. They are classified as a relational process, mental process, and material process. The mental process is the predicate 'will delight', which is categorized as emotive 'please' type verb. 
Data 23: Taste delicious local fruit and vegetables, untainted by chemicals and pesticides; pay witness to the Latvian rural idyll where small family-run farms continue to operate much in the same way as they have done for centuries, maintaining the traditional rural way of life for this ecologicallyminded nation's next generation.

The datum above contains five clauses. There are two mental processes. First, the word 'taste' belongs to perceptive 'like' type verb, while the second word, 'untainted' belongs to emotive 'please' type verb.

Data 24: Latvian cuisine is best enjoyed slowly with a glass of local beer or a soothing cup of herbal tea.

The predicate of the clause above is 'is enjoyed', which belongs to emotive 'like' type verb.

Data 25: But, if you are feeling homesick, or wish to try something new and different, Latvia's town and cities, and the capital Riga in particular, are home to an amazing array of restaurants offering international cuisine to suit every palette.

There are three clauses found from the datum above. They are classified as mental processes and a relational process. The predicate 'are feeling' is categorized as perceptive 'like' type, while the word 'wish' belongs to desiderative 'like' type verb.

Data 26: Escape from it all and enjoy unique festivals, colorful seasonal celebrations, and top international sporting events.

There are two clauses from the analysis of the datum above. Both of them are mental processes. The word 'escape' belongs to the cognitive 'please' type verb, while the second one, the word enjoy belongs to emotive 'like' type verb.

Data 27: In Latvia the visitor is encouraged to experience something new; something unique and unforgettable.

The mental process found from the datum above is 'is encouraged'. It is classified as emotive 'like' type verb.

Data 28: As the Earth's seasonal cycle sees snowy winters turn into the bright fresh rebirth of Spring, and the warm white nights of midsummer slowly pass to give way to the autumn time of harvest, Latvians mark appreciate each of these changes with traditional seasonal celebrations and colourful city festivals.

There are four clauses in the datum above. The mental processes found are only two. They are the words 'sees' and 'appreciate'. The word 'sees' is categorized as perceptive 'like' type verb, while the word 'appreciate' is cognitive 'like' type verb. 
Data 29: See Riga in a , different light ' during the annual Staro Riga Festival of Light, held each November, when the historic part of the city is bathed in unusual and imaginative patterns of light that give whole new perspectives to Riga's parks and historical monuments.

The same as the datum number 28 , the clauses are four, but the mental process found is only one, the word 'see'. It belongs to the perceptive 'like' type verb.

Data 30: We all love sport, but Latvians hold a particular affection for both spectator and participation sport.

There are two clauses in the datum above. The word love is emotive 'like' type verb.

Data 31: Relax and enjoy 530 kilometres of pristine white sand beaches, where the sea breeze is always fresh and the fragrant smell of pine forests never far off. verb.

The words 'relax' and the word 'enjoy' are classified as emotive 'like' type

Data 32: Enjoy a wild fish picnic on the deserted Baltic Sea coast or sit and watch children playing on the shores of the Gulf of Riga.

There are the words 'enjoy' and 'watch' in the datum above. The word enjoy is emotive 'like' type verb, while the word watch is perceptive 'like' type.

Data 33: Relax and enjoy soothing massages, indulgent facials, slimming body wraps, and health-boosting medical spa treatments.

The analysis of datum number 33 is the same as the analysis of datum number 31. The words 'relax' and the word 'enjoy' are classified as emotive 'like' type verb.

Data 34: Indulge yourself in the unique and enjoy an unforgettable experience that will stay with you long after you have left Latvia and returned home to the more ordinary.

There are five clauses in the datum above. Two clauses, in the beginning, are classified as mental processes, while the three clauses at the end are categorized as the material processes. The words 'indulge' and 'enjoy' belong to emotive 'like' type verbs. 


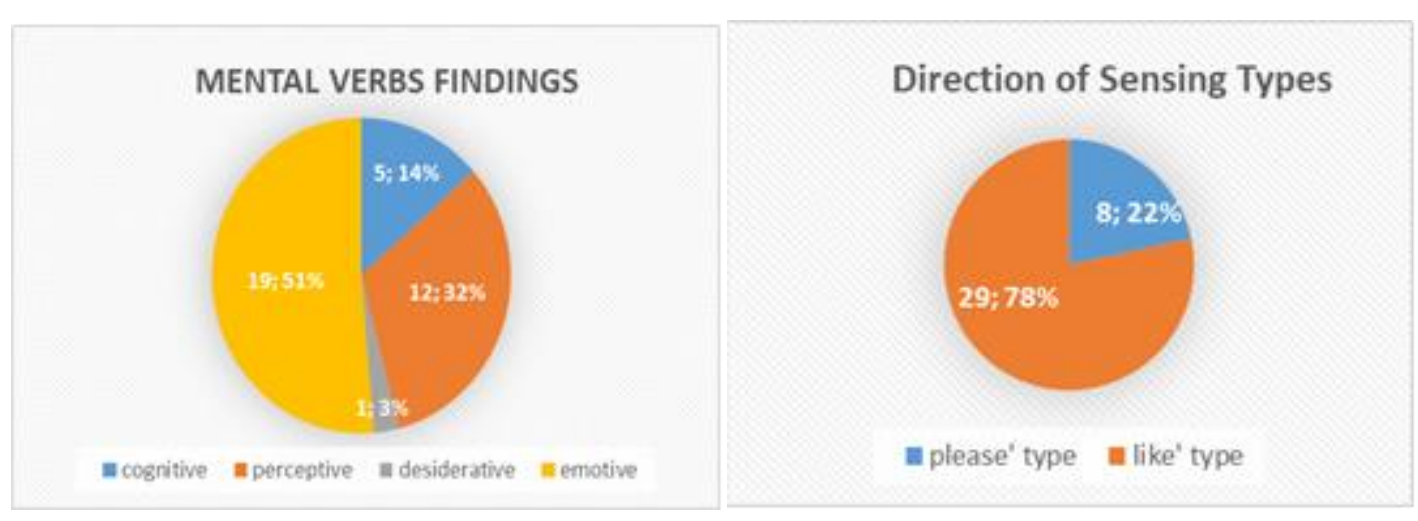

Figure 2. Findings of Mental/Sensing Verbs

\section{Discussion}

The process of sensing is the process of feeling, thinking, wanting, and perceiving. It represents the states of consciousness. The study shows that in Latvia's tourism booklets, the dominant process of sensing or the mental processes is the emotive 'like' verbs, which are 19 emotive mental or sensing verbs or $51 \%$ of the 37 verbs. The second rank is the perceptive verbs, which is 12 data or $32 \%$. The third is $14 \%$ or 5 cognitive verbs. The last is the desiderative verbs with only 1 verb found. Based on the direction of sensing, the study shows that in Lavia's tourism booklets, there are 29 'like' types or $29 \%$ of the total data. While the 'please' types are 8 or $22 \%$ of the total data. The mostly used sensing verbs are the word 'enjoy' ( 7 data), then followed by the word 'feel' ( 6 data). The writer also finds some sensing verbs that are not shown in the table suggested by Halliday, such as the verbs 'attracts, admire, escape, indulge, and untrained. To solve this problem, she analyzes the findings by making the synonyms or finds the nearest meaning of the verbs.

As the writer's first hypothesis that in the tourism booklets or texts there will be found the sensing or the mental verbs, this study shows the same phenomena. The sensing or mental verbs as the linguists expert stated that these verbs are no material actions, but describes the states of mind or psychological events perfectly match with the findings that the sensing or mental verbs or sometimes are called the statis verbs play emotionally, intellectually, and sensorily. By doing this study, the writer believes that it is will expand the point of views in understanding the process of sensing or the mental processes. She also believes that it can contribute to understanding the similar research problem within the field of mental processes study. Some interesting topics will be useful for the further study, for instance why the emotive verbs or 'like' types are mostly used in the tourism text, or it can be a comparative study of the process of sensing in the other tourism booklets, because this study only finds the process of sensing in Latvia's tourism booklets. 


\section{CONCLUSION}

Based on the analyses in the result and discussion, it can be concluded that the first level of the most appearing verb of sensing process is categorized as emotive 'like' types of sensing process. The next level is the perceptive 'like' type verbs, then followed by emotive 'please' type and cognitive 'like' type. There are no perceptive 'please' and cognitive 'please' verbs, while the finding of the desiderative type is only one verb. The emotive 'like' types verbs mostly appear in the tourism booklets proof us that they play an important role in persuading and influencing the people who read the booklets emotionally. Emotion plays an important role to change people's minds.

\section{BIBLIOGRAPHY}

Bloor, Thomas, and Bloor, Meriel. (2004). the Functional Analysis of English Second Edition. Hodder Education: London.

Deterding, David H., \& Poedjosoedarmo, Gloria R. (2001). Grammar of English. Singapore. Prentice Hall.

Gerot, Linda, \& Wignell, Peter, (1995). Making Sense of Functional Grammar. Second Edition, Sydney. Gerd Stabler.

Halliday, M. A. K. (2004). An Introduction to Functional Grammar. Third Edition, London. Edward. Quirk, Randolf et al.

Moleong, J. Lexy, (2000). Metode Penelitian Kualitatif. Bandung. PT Remaja Rosdakarya.

Sujatna, Eva Tuckyta Sari, (2012). Applying Systemic Functional Linguistics to Bahasa Indonesia Clauses.

http://www.macrothink.org/journal/index.php/ijl/article/view/1506

Sujatna, Eva Tuckyta Sari, (2012). Sundanese Verbs in Mental Processes: A Systemic Functional Linguistic Approach.

http://www.macrothink.org/journal/index.php/ij1/article/viewFile/2577/pdf

Sujatna, Eva Tuckyta Sari. (2016). Processes in Bahasa Indonesia Tourism Promotion Texts and Its Equivalence in English: A Systemic Functional Linguistic Study. International Journal of English Linguistics; Vol. 6, No. 4, Canadian Center of Science and Education.

http://www.latvia.travel/en/news/tourism-development-agency-issues-new-bookletstourism-opportunities-and-around-riga-and-medica 